\title{
Intersections
}

Canadian Journal of Music

Revue canadienne de musique

\section{John Beckwith. 2006. In Search of Alberto Guerrero. Waterloo: Wilfrid Laurier Press, xviii, 159 pp. ISBN-13: 978-0-88920-496-6 (paperback)}

\section{Gordon E. Smith}

Volume 26, numéro 1, 2005

URI : https://id.erudit.org/iderudit/1013247ar

DOI : https://doi.org/10.7202/1013247ar

Aller au sommaire du numéro

Éditeur(s)

Canadian University Music Society / Société de musique des universités canadiennes

ISSN

1911-0146 (imprimé)

1918-512X (numérique)

Découvrir la revue

Citer ce compte rendu

Smith, G. E. (2005). Compte rendu de [John Beckwith. 2006. In Search of Alberto

Guerrero. Waterloo: Wilfrid Laurier Press, xviii, 159 pp. ISBN-13:

978-0-88920-496-6 (paperback)]. Intersections, 26(1), 148-152.

https://doi.org/10.7202/1013247ar

Copyright @ Canadian University Music Society / Société de musique des universités canadiennes, 2006
Ce document est protégé par la loi sur le droit d'auteur. L'utilisation des services d'Érudit (y compris la reproduction) est assujettie à sa politique d'utilisation que vous pouvez consulter en ligne.

https://apropos.erudit.org/fr/usagers/politique-dutilisation/ 


\section{BOOK REVIEWS/RECENSIONS}

John Beckwith. 2006. In Search of Alberto Guerrero. Waterloo: Wilfrid Laurier Press. xviii, 159 pp. ISBN-13: 978-0-88920-496-6 (paperback).

John Beckwith's recent book on the pianist Alberto Guerrero is a compelling narrative about a fascinating figure on the Canadian, especially Toronto, musical scene for more than forty years of the last century (1918-1959). In Search of Alberto Guerrero also confirms Beckwith's own reputation as one of the most widely respected researchers on Canadian music history today. It is not just Beckwith's impeccable scholarship that makes his work distinctive, but as Beverley Diamond has written, Beckwith's "insistence that we look carefully at social realities" as a means of understanding culture is also a pervasive aspect of his work, one that facilitates interpreting music in broad contexts, and one that engages reflexive modes of thinking and writing about music (Diamond 1995, 273). A decided strength of Beckwith's book is that he presents multiple narratives, weaving into the Guerrero story historical and contemporary perspectives, local voices, and importantly, his own voice, as a former piano student of Guerrero. As he writes in the book's Introduction: "If the story has two parts, my narration itself takes two tones-part objective research and part personal memoir" (xviii). The book has six chapters, four appendices, an index, and nearly thirty illustrations.

Beckwith's research for In Search of Alberto Guerrero included a stint in Guerrero's country of birth, Chile, in January 2003, during which Beckwith examined documents and interviewed individuals about Guerrero and his family in Santiago and La Serena, Guerrero's birthplace. Beckwith was also fortunate to have had the assistance of Nieves Carrasco, a Chilean living in Toronto, who was instrumental in pointing Beckwith to many valuable records. Alberto García Guerrero (1886-1959) spent the first thirty-two years of his life in his native Chile, and moved to Canada in 1918, where he lived until his death. In the first two chapters, Beckwith explores Guerrero's Chilean background, focusing on his family, education, and early career as a performing artist. We read, for example, that even though Guerrero came from a large family of seven children, his two brothers, Daniel, a physician, and Eduardo, who had a career in law appear to have been his closest siblings. Along with their professional careers, both brothers were amateur musicians and supported the young Guerrero's early musical career. Eduardo, for example, at times appeared as a commentator in lecture-recitals with Alberto, and Daniel, a pianist, was an "avid and accomplished musical dilettante" (p. 5), who, along with Nicolasa Guerrero, their mother, is said to have taught piano to Alberto. Beckwith explains also 
that Guerrero later adopted his mother's name rather than his father's, García, which would have been more conventional, but may have also been a sign of Guerrero's greater devotion to his mother.

Details surrounding Guerrero's musical education are not complete, and Beckwith maintains that there is room for more research about this aspect of the Chilean part of Guerrero's story. It is not clear, for instance, if Guerrero attended the Conservatorio Nacional in Santiago, whereas we know that two of Guerrero's close musical colleagues, Alfonso Leng, a cellist, and Domingo Santa Cruz, a diplomat and founder of the Faculty of Fine Arts at the Universidad de Chile in the late 1920s, both studied with Enrique Soro, a composition teacher at the Conservatorio in Santiago. The idea that Guerrero was exceptionally gifted as a musician and a pianist from a young age and could have been largely self taught is worth speculation, given his creative activities as a composer and a performer in the period up to 1918, when he left Chile for Canada. How, Beckwith asks, did Guerrero compose music for five light operas, chamber music, songs, piano pieces, and possibly works for orchestra, without professional instruction? And it is not clear from current records whether Guerrero had contact, let alone instruction, from at least two leading pianists of the period, Ricardo Viñes, and Isidor Philipp (p. 5). We also learn that Guerrero was an author of critical and analytical writings on music, including two treatises on harmony and piano technique, respectively. For whatever reasons, these writings have all been lost, a piece of the Guerrero puzzle that would surely yield more light on Guerrero's musical perspectives and knowledge, should they ever be found.

Particularly informative and engaging aspects of Guerrero's Chilean background are in Beckwith's description of Guerrero's success as a composer for stage works, a compositional genre for which Guerrero appears to have had a special affinity. These stage works, sometimes known as zarzuela, often drew on regional contexts for their content, an aspect of the genre that Beckwith compares (coincidentally) to light operas composed in Canada by Joseph Vézina (1849-1924). Beckwith's point of comparison is in two works (Rucacahuin by Aurelio Díaz Meza and Guerrero, 1908, and Le Fétiche, 1912, by Vézina) and is focused on disappearing ways of life of aboriginal peoples, a theme which was, as Beckwith suggests, pervasive across national borders. In addition to what we learn about Guerrero's work as a composer, equally informative are the details Beckwith provides regarding his work as a solo and chamber performer, including repertoire choices and commentaries on Guerrero as a performer. By 1915, the year Guerrero married his first wife, Elena ("Lily") Wilson, Guerrero appears to have had an established reputation as a performer. That year, he had a successful tour, performing joint concerts with the Dutch cellist Michael Penha in principal cities in Peru, Bolivia, Panama, Costa Rica, and Cuba. The last stop on the tour was New York City where Guerrero performed and lived for a year and half, and where Guerrero had his first Canadian contact through a chance meeting with pianist Mark Hambourg. It was Hambourg who told Guerrero about a position at the newly established Hambourg Conservatory of Music in Toronto. At the end of chapter two in a section called "Why?", Beckwith speculates on the reasons why Guerrero left "his position as a front-ranking performer in Chile 
... in favour of a career in what might have justifiably been called a musical backwater like Toronto ... and why, having done so, did he turn his back on family and friends in Chile and never return?" (p. 44). Beckwith provides partial answers to these questions, such as economic considerations and surviving the taxing life of the concert circuit.

The Canadian part of Guerrero's story comprises the balance of In Search of Alberto Guerrero (chapters 3-6) and is as equally thoroughly researched as the opening chapters on the Chilean context. In this part of the book, we also hear Beckwith's voice more prominently, both in terms of his association with Guerrero and those in Guerrero's circle in the last two decades of his life, and also in Beckwith's descriptions of musical and social aspects of life in Toronto in that period. With his "international" reputation, Guerrero quickly became a prominent figure in Toronto as a teacher and a performer. From Beckwith's account, it appears that Guerrero's first twenty years in Toronto were most active as a solo and chamber performer, including concerts at Hart House in the University of Toronto and at the Toronto Conservatory of Music (designated as "Royal" after 1947), as a soloist with the Toronto Symphony Orchestra and at the popular summer Promenade Concerts, and as a soloist and chamber player in Eaton Auditorium (opened in 1931).

Guerrero's repertoire was extensive, ranging from Bach's Goldberg Variations, "... a work that at the time was a rarity known, if at all" (p. 82), to solo works by Scarlatti, C.P.E. Bach, Haydn, Mozart, Beethoven, Chopin, through to works by Debussy, Satie, Hindemith, Villa-Lobos, da Falla, Albéniz, among others. From Beckwith's detailed examination of Guerrero's concertizing, we also see Guerrero's versatility as a performer, including playing the popular Grieg Piano Concerto at the summer Promenade Concerts on two occasions and playing the extremely demanding piano part in Stravinsky's Petrushka Suite in the Toronto Symphony Orchestra's first performance of this work in 1934, again in the 193536 season, and on a third occasion in 1937, with Stravinsky as guest conductor. Beckwith relates that, long after this event, Guerrero spoke of "his pleasant brief association with the composer, who, he recalled, appreciated Guerrero as someone well acquainted with his [Stravinsky's] music" (p. 67). Beckwith goes on to say that Guerrero had performed Stravinsky's Piano Sonata and that he had also made "a brilliant impression" with his 1932 Eaton Auditorium performances of the Petrushka suite that Stravinsky had arranged for the pianist Arthur Rubinstein. Alongside his concertizing as a soloist, Guerrero was an avid chamber music player and collaborator. From 1926 to least 1940, Guerrero was a member of the Five Piano Ensemble, a collaborative group of Toronto pianists that featured arrangements of popular favorites in its programming. Sponsored by Heintzman and Company, the idea of piano "teams" was apparently popular in Toronto, "a great piano town" (p. 83), as a Ten Piano Ensemble was begun in the early 1930s seemingly as a rival effort. This "popular" collaborative work with the Five Piano Ensemble was a complement to Guerrero's other work as a performer and, as Beckwith points out, provides "a striking parallel to his emphasis on zarzuela composition simultaneously with his groundbreaking new-music efforts in Chile years before: producing music for wide popular appeal and for 
connoisseurs did not represent an either-or choice for him; both were desirable and important" (p. 83).

In addition to his Canadian career as a performer, Guerrero also had a distinguished reputation as a teacher and mentor. Guerrero's role as a teacher is a major theme throughout the four chapters of In Search of Alberto Guerrero devoted to Guerrero's musical life in Canada. Guerrero taught at the Hambourg Conservatory upon his arrival in Toronto in 1918 and began a long association as a teacher and examiner with the Toronto (Royal) Conservatory soon after in 1922. From the 1920s through to the 1950s, Guerrero's pupils included many individuals who went on to have their own careers and influence as musicians and teachers: Horace Lapp, Margaret Clemens, Eva Galloway Farmer, and Adele Doney in the early period (p. 57), Gwendolyn Duchemin, Alexandra McGavin, Victor Dell, and Laurence Morton (p. 86) in the 1940s, and William Aide, Paul Helmer, Pierrette Lepage, Margaret Sheppard, Arthur Ozolins, Edward Laufer, Ray Dudley, in the later 1940s through into the 1950s, and Beckwith, himself, 1945-50. Two of Guerrero's most notable pupils were Myrtle Rose who, from the 1930s, became Guerrero's lifelong partner (he had separated from Lily in 1931), and Glenn Gould, whom Guerrero taught from 1942 until 1951. For decades following Guerrero's death, Guerrero's reputation appeared to rest on the fact that he had been Gould's teacher. As Beckwith writes: "The mystique surrounding Gould's miraculous career has allotted Guerrero a curious and distorted role-more or less that of a kindly, indulgent old uncle" (p. 100). In In Search of Alberto Guerrero, Beckwith's documentation of Gould's association as a pupil of Guerrero is put in context by his consideration of Guerrero's work with Gould and with other gifted students, by describing Guerrero's own career as a performer, and, indeed, by the more complete story we read about Guerrero throughout the book.

For me, a most engaging part of Beckwith's book is his own "story" about Guerrero, including how it was Guerrero's recommendation that led Beckwith to Toronto to study with him, and how formative an influence Guerrero really was on Beckwith's musical education. At this point, the Guerrero story intersects with the Beckwith story in subtle ways. In Beckwith's voice, we learn about Guerrero's personality, teaching style, and distinctive approaches to technique and interpretation. In this narrative, we hear voices of other Guerrero pupils, also colleagues and friends of Beckwith's such as Margaret Sheppard and Ray Dudley (the book is dedicated to Dudley, who passed away in 1994 during Beckwith's writing of the book), as well as that of Guerrero's only child, daughter Mélisande Irvine, an artist who painted the telling portrait of her father shown on the book's cover. Significantly, the book's final chapter concludes with a series of quotations by former Guerrero pupils (p. 126), followed by an appendix in which we hear Guerrero's own voice on "The Discrepancy between Performance and Technique." The book's three other appendices provides other voices: appendix 2 is an obituary written by Royal Conservatory Principal, Boyd $\mathrm{Neel}$, and appendices 3 and 4 deal with a symposium titled "Remembering Alberto Guerrero," organized by Beckwith and held at the Faculty of Music at the 
University of Toronto in October, 1990 (appendix 3 is a list of participants, and appendix 4 is a symposium program excerpt written by Beckwith).

In Search of Alberto Guerrero is a fascinating account of a heretofore mostly unknown, and at times, unappreciated figure in Canadian music. Beckwith's thorough research and his varied approaches to narrative in writing about music in historical, contemporary, and social contexts, bring alive the multiple stories that surround Alberto Guerrero and make this book a great read. I conclude with Beckwith's own words: "With Guerrero, the piano plugged you into music, music plugged you into all the other arts, and altogether they plugged you into life" (p. 136). For those of us who have had the honour of knowing John Beckwith as a teacher, mentor, colleague and friend, these words will surely have a special resonance.

\section{REFERENCE}

Beverley Diamond. 1995. "Narratives in Canadian Music History," in Taking a Stand: Essays in Honour of John Beckwith, 273-305. Toronto: University of Toronto Press.

Gordon E. SMITH

Andreas Jacob. 2005. Grundbegriffe der Musiktheorie Arnold Schönbergs. 2 vols. Hildesheim: Georg Olms. 1080 p. ISBN 3-487-1295-7 (hardcover).

Recent Schoenberg research in Europe has tended toward biography, social setting, reception, and the composer's prose writings, rather than toward the scores and their performances. Situated within that tendency, the writings on Schoenberg's music theories have exerted an important attraction, important in the sense of both size and critical interest. This attraction is not confined merely to Europe; Schoenberg translations have become something of a minor musicological industry in North America. The book in question here, Andreas Jacob's two-volume overview of the theoretical issues at hand in Schoenberg's thought, must be considered the leading edge of theoretical work undertaken on Schoenberg's manuscripts. It will prove requisite for any scholar (from any quarter of the world) with an interest in Schoenberg's theories and their manuscript legacy. Indeed the importance of Schoenberg's thought to modern music theory makes this a "must have" for scholars and institutions with a research interest in twentieth-century theoretical thought in general.

The first volume of the book is entitled "Darstellung," "Representation", a word redolent with associations for Schoenberg scholars. Darstellung is what Schoenberg promised as he set forth the aims of his text on harmony, in the introductory chapters to the Harmonielehre (1911). By the term he meant simply a representation of the essential ideas-a representation of, and thus not the ideas themselves. Other theorists made the mistake of presenting essential ideas as if in their natural form. (One such idea proposed that diatonic tonality was 